\title{
Meteorological factors responsible for the growth and development of sugarcane at two locations in Rio Grande do Sul, Brazil
}

\author{
Fábio Miguel Knapp ${ }^{1^{*}}$ (D) Jaqueline Sgarbossa ${ }^{2}$ (D) Claiton Nardini $^{3}$ iD Denise Schmidt $^{3}$ (iD \\ Liliane Bárbara Tibolla ${ }^{4}$ iD Sandro Luis Petter Medeiros ${ }^{2}$ (iD) Braulio Otomar Caron ${ }^{3}$ (D)
}

\footnotetext{
${ }^{1}$ Departamento de Engenharia de Biossistemas, Escola de Agronomia, Universidade Federal de Goiás (UFG), 74690-900, Goiânia, GO, Brasil. E-mail: fabio.knapp@hotmail.com. *Corresponding author.

${ }^{2}$ Departamento de Fitotecnia, Universidade Federal de Santa Maria (UFSM), Santa Maria, RS, Brasil.

${ }^{3}$ Departamento de Ciências Agronômicas e Ambientais, Universidade Federal de Santa Maria (UFSM), Frederico Westphalen, RS, Brasil.
}

${ }^{4}$ Desenvolvimento de Mercado, Instituto Mato-Grossense do Algodão, Cuiabá, MT, Brasil.

\begin{abstract}
This study determined the meteorological variable that most contribute to the productivity of sugarcane stalks in the northwest and central regions of Rio Grande do Sul. The following sugarcane genotypes were used: UFSM XIKA FW, UFSM LUCI FW, UFSM PRETA FW, UFSM DINA FW, UFSM MARI FW, and IAC87-3396. The UFSM cultivars originate from a mutation process in the breeding program conducted at the Federal University of Santa Maria, Frederico Westphalen campus, and have low temperature tolerance. The productivityassociated morphological characters included in the models were average stem diameter, average stem number per meter of furrow, and average stem height. The following meteorological variables were used: minimum air temperature, precipitation, incident solar radiation, and accumulated thermal sum. Pearson's correlation, canonical correlations, and Stepwise regression were performed between morphological characters and meteorological variables: minimum air temperature had the greatest influence on sugarcane productivity in the studied regions, and accumulated thermal sum showed the highest correlation and contributed most to stem diameter and average stem height. Thus, the models indicated that the growth of sugarcane is positively associated with the accumulated thermal sum, and sugarcane can be cultivated at the studied regions.
\end{abstract}

Key words: Saccharum spp., degree-days, multiple regression, canonical correlation.

Fatores meteorológicos responsáveis pelo crescimento e desenvolvimento da cana-de-açúcar em dois locais do Rio Grande do Sul

RESUMO: $O$ objetivo deste trabalho foi determinar a variável meteorológica com maior contribuição na produtividade de colmos de canade-açúcar na região noroeste e central do Rio Grande do Sul. Os genótipos de cana-de-açúcar utilizados foram: UFSM XIKA FW, UFSM LUCI FW, UFSM PRETA FW, UFSM DINA FW, UFSM MARI FW, IAC87-3396. As cultivares UFSM são provenientes do processo de mutação do programa de melhoramento da Universidade Federal de Santa Maria, campus de Frederico Westphalen, e possuem tolerância a baixas temperaturas. Os caracteres morfológicos responsáveis pela produtividade utilizados nos modelos foram diâmetro médio de colmo, número médio de colmos por metro de sulco e estatura média de colmos. As variáveis meteorológicas utilizadas foram a temperatura mínima do ar, precipitação pluviométrica, radiação solar incidente e soma térmica acumulada. Foi realizada a correlação de Pearson, correlações canônicas e regressão de Stepwise entre os caracteres morfológicos e as variáveis meteorológicas, nos quais foi constado que a temperatura mínima do ar é a variável com maior influência na produtividade da cana-de-açúcar nas regiões estudadas e, que a soma térmica acumulada é a variável com maior correlação e contribuição no diâmetro de colmo e estatura média dos colmos. Desse modo, os modelos indicam que o crescimento da cana-de-açúcar responde de forma positiva a soma térmica acumulada, e as regiões em estudo apresentam potencial para o cultivo da cana-de-açúcar.

Palavras-chave: Saccharum spp., graus-dia, regressão múltipla, correlação canônica.

\section{INTRODUCTION}

Sugarcane (Saccharum ssp.) is one of the main crops of agronomic interest and is grown worldwide (CAPUTO et al., 2008). The distinguishing feature of this crop is its high potential to produce biomass and energy per unit area (SILVA et al.,
2014), because of which it is used as raw material to produce sugar (FAO, 2019) and ethanol (WALTER et al., 2014). Brazil is one of the largest producers of sugarcane, with about 8.4 million hectares (ha) of planted area, production of 642.7 million tons, and average productivity of 76.1 tons $\mathrm{ha}^{-1}$ in the 2019/2020 crop season (CONAB, 2020). 
Techniques such as models for forecasting sugarcane productivity are important strategies for the operational management of the sugar-energy industry, influencing agricultural decisions and the operation and maintenance of the industry (BOCCA \& RODRIGUES, 2016; EVERINGHAM et al., 2016; PAGANI et al., 2017). Simulation models of the growth and development of sugarcane can simulate different scenarios and ways to optimize resources and increase the understanding of the processes related to growth and productivity (SUGUITANI, 2006).

Sugarcane productivity can be simulated using variables such as stem diameter, stem number per linear meter of furrow, and plant height (MARTINS \& LANDELL, 1995; OLIVEIRA et al., 2007; FABRIS et al., 2013). In this context, the use of multivariate techniques such as canonical correlations allows the determination of the associations between groups of characters and identification of characteristics and important variables for analyzing the performance of crops (CARVALHO et al., 2015).

The growth and development of plants and; consequently, the productivity of crops, are associated with several biotic and abiotic factors, with meteorological elements being the most relevant (SCHWERZ, 2020). The effect of meteorological elements on crops can be analyzed using statistical techniques such as stepwise regression, which is the most used. The method consists of testing the insertion or removal of independent variables in equations by using statistical significance and the correlation coefficient between dependent and independent variables as criteria (FIORENTIN et al., 2015).

Assuming that the minimum air temperature is the main limiting factor for the productivity of sugarcane stalks in southern Brazil, this study determined and quantified the influence of meteorological variables on the productivity of sugarcane cultivated in different regions of Rio Grande do Sul by analyzing the canonical correlation between morphological characters and meteorological variables and generating linear regression models from variables for each associated character.

\section{MATERIALS AND METHODS}

In this study, two field experiments were conducted from October 2017 to July 2018. The first experiment was conducted in the micro-region of Frederico Westphalen, in the state of Rio Grande do Sul, Brazil, in the Federal University of Santa Maria, with geographical coordinates $27^{\circ} 39^{\prime} 56^{\prime \prime}$ LS- $53^{\circ} 42^{\prime} 94^{\prime \prime} \mathrm{LW}$ and altitude of $566 \mathrm{~m}$. According to the Köppen climate classification, the climate is Cfa type, subtropical with no defined dry season, with average annual air temperature of $19.1^{\circ} \mathrm{C}$ (range, 0 to $38^{\circ} \mathrm{C}$ ) and accumulated precipitation of 1900 $2200 \mathrm{~mm}$ (ALVARES et al., 2013). The soil of the experimental area is classified as Latossolo Vermelho aluminoférrico, with $67 \%$ clay, $2.5 \%$ organic matter (OM), $2.8 \mathrm{mg} \mathrm{dm}^{-3}$ of P, $139 \mathrm{mg} \mathrm{dm}^{-3}$ of K, $14.1 \mathrm{cmolc}$ $\mathrm{dm}^{-3}$ of chlortetracycline (CTC), and base saturation of $55.9 \%$.

The second experiment was conducted in the micro-region of Cruz Alta, in the state of Rio Grande do Sul, Brazil, in a rural property, with geographical coordinates $28^{\circ} 42^{\prime} 36^{\prime \prime} \mathrm{S}$ and 53 $43^{\prime} 12^{\prime \prime}$ $\mathrm{W}$ and altitude of $452 \mathrm{~m}$. According to the Köppen climate classification, the climate is Cfa type, subtropical with no defined dry season, and average air temperature of $19.0^{\circ} \mathrm{C}$ (range, -1 to $38^{\circ} \mathrm{C}$ ) for the hottest and coldest months, respectively, and accumulated precipitation of 1900 to $2200 \mathrm{~mm}$ (ALVARES et al., 2013). The soil in the experimental area is classified as a typical Latossolo Vermelho distroférrico, with $56 \%$ clay, $2.8 \% \mathrm{OM}, 4.0 \mathrm{mg} \mathrm{d}^{-3}$ of $\mathrm{P}, 88 \mathrm{mg} \mathrm{dm}^{-3}$ of K, $10.8 \mathrm{cmolc} \mathrm{dm}^{-3}$ of CTC, and base saturation of $54.9 \%$.

The experiment conducted in the microregion of Frederico Westphalen followed a randomized block design with a $6 \times 2$ factorial arrangement and treatments consisting of six cultivars-UFSM XIKA FW, UFSM MARI FW, UFSM DINA FW, UFSM PRETA FW, UFSM LUCI FW, and IAC87-3396arranged in two row spacings $(0.33 \mathrm{~m} \times 1.5 \mathrm{~m}$ and 0.5 $\mathrm{m} \times 1.5 \mathrm{~m}$ ), with four replications. The experiment conducted in the micro-region of Cruz Alta followed a randomized block design with treatments consisting of the six above-mentioned cultivars arranged in a single row spacing $(0.5 \mathrm{~m} \times 1.5 \mathrm{~m})$, with four replications.

The first five sugarcane cultivars used in both the experiments are protected materials at the Ministry of AgriCROP, Livestock, and Supply by Federal University of Santa Maria, and cultivar IAC87-3396 was selected because this genotype was used for inducing mutations to obtain the UFSM FW cultivars. UFSM FW cultivars are the first sugarcane cultivars protected by the Federal University of Santa Maria in the Ministry of AgriCROP, Livestock, and Supply and the first ones to be generated by mutation induction. The generation of new cultivars was confirmed by their morphological characters that were clearly distinguishable from those of the cultivar from which they originated, according to 
the guidelines regulated by law No. $9.456 / 97$ of protection of cultivars.

The plant material used in this study was obtained by the propagation of pre-sprouted seedlings, with the planting of small stalks on June 28, 2017, in a protected environment and transplantation on October 18, 2017, in Frederico Westphalen, RS, and on October 29, 2017, in Cruz Alta, RS. Before the seedlings were transplanted, the soil was prepared for planting the seedlings by adjusting the $\mathrm{pH}$, generating two subsoils, and securing a harrowing area for incorporating lime. Each row was fertilized with NPK, according to the technical indications for cultivation in the states of RS and SC (SOCIEDADE BRASILEIRA DE CIÊNCIA DO SOLO, 2016): 100 $\mathrm{kg}$ of $\mathrm{N}, 110$ of $\mathrm{P}_{2} \mathrm{O}_{5}$, and $60 \mathrm{~kg}$ of $\mathrm{K}_{2} \mathrm{O}$ were used in Frederico Westphalen; $70 \mathrm{~kg}$ of N, 110 of $\mathrm{P}_{2} \mathrm{O}_{5}$, and $60 \mathrm{~kg}$ of $\mathrm{K}_{2} \mathrm{O}$ were used in Cruz Alta.

The data on incident global radiation, air temperature (minimum, average, and maximum), and precipitation were obtained from automatic meteorological stations linked to the National Institute of Meteorology (INMET) of Frederico Westphalen and Cruz Alta, which are located 500 $\mathrm{m}$ and $10,000 \mathrm{~m}$ from the experimental areas, respectively. The water balance for both locations was determined according to the methodology proposed by Rolim et al. (1998) (Figure 1). The available water capacity in the soil (AWC) needed to be measured to calculate the sequential water balance, which yielded values of $157 \mathrm{~mm}$ and $113 \mathrm{~mm}$ for Frederico Westphalen and Cruz Alta, respectively. For this, the meteorological data were grouped into ten-day periods, and the period for transplanting the sugarcane harvest was considered to be 27 periods.

At 38, 73, 103, 147, 175, 224, and 266 days after transplantation, biometric measurements of stem diameter were performed at the basal portion, close to the ground (MARTINS \& LANDELL, 1995), and the height of the tillers with two stems per experimental unit and number of tillers per linear meter of furrow were determined. This count was performed on $2 \mathrm{~m}$ of the two central rows of a plot, totaling 4 linear meters per plot. The accumulation of stalk mass was determined on the basis of these data, which revealed the main morphological characters and determinants of stalk productivity per hectare

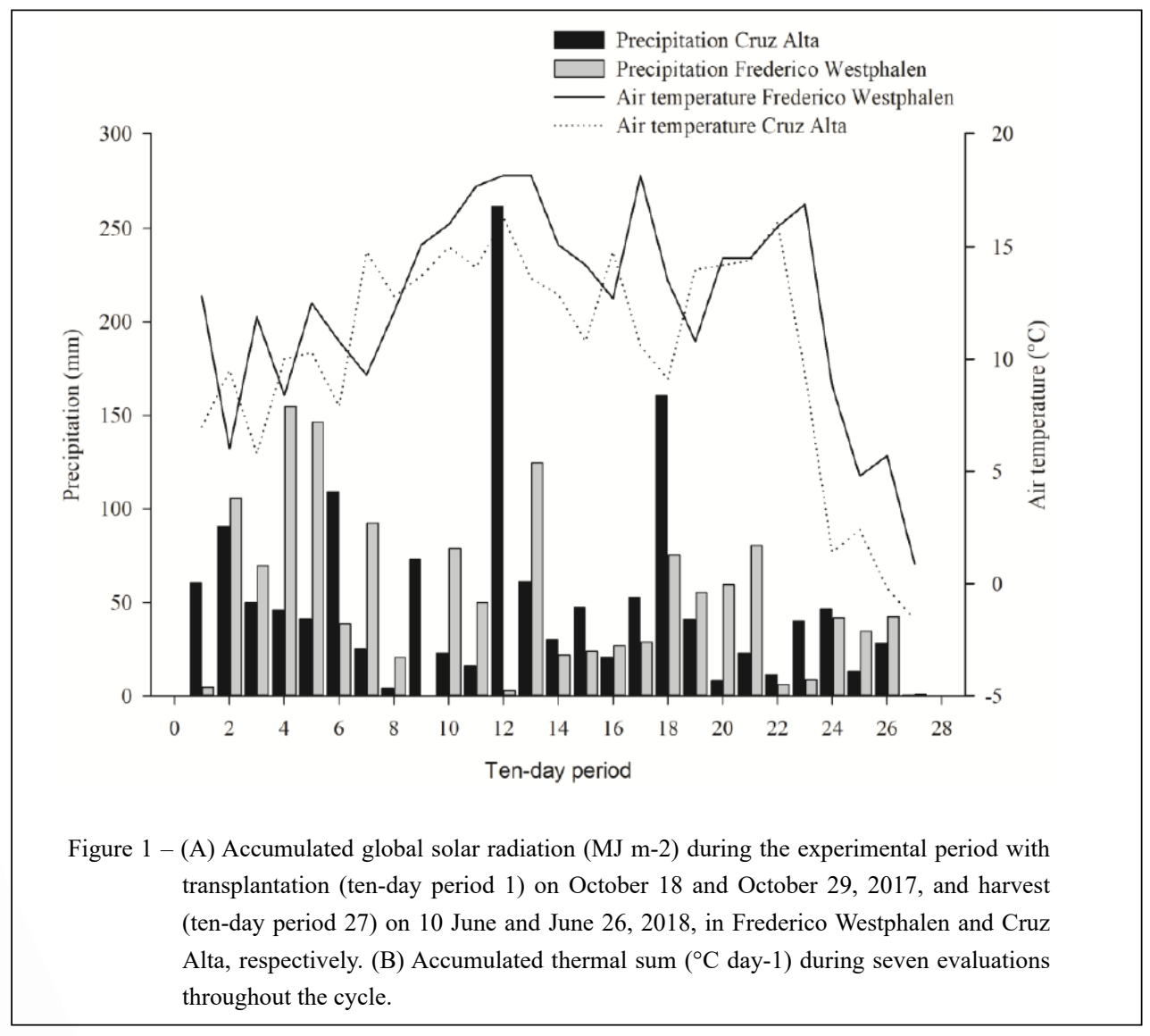

Ciência Rural, v.51, n.10, 2021. 
(MARTINS \& LANDELL, 1995; OLIVEIRA et al., 2007; FABRIS et al., 2013).

The daily thermal sum was determined by considering the lower baseline temperature $(\mathrm{Tb})$ of $10^{\circ} \mathrm{C}$ for the cultivation of sugarcane (STRECK et al., 2010; CASTRO-NAVA et al., 2016; MORAIS et al., 2018), i.e., the degrees-day $\left(\mathrm{DD}_{\mathrm{i}}\right)$. It was obtained using the following equations for days when the minimum temperature was higher than the Tb (NOVA et al., 1972; PEREIRA et al., 2002).

$\mathrm{DD}_{\mathrm{i}}=\mathrm{Tm}-\mathrm{Tb}$

Where, Tm represents the average temperature on the days when the Tb was greater than or equal to the minimum temperature (Tmin):

$\mathrm{DD}_{\mathrm{i}}=\frac{(\mathrm{TM}-\mathrm{Tb})^{2}}{2(\mathrm{TM}-\mathrm{Tm})}$

Where, TM and Tm represent the maximum and minimum temperature of the day, respectively.

The accumulated thermal sum or accumulation of $\mathrm{DD}_{\mathrm{i}}$ from the transplanting date to emergence resulted in the sum of degrees-day ( $\left.\sum D D\right)$, which is the thermal constant necessary for plants to grow and/or develop.
The data were statistically analyzed using the Statistical Analysis System version 9.0 (SAS, 2002). Initially, the statistical assumptions of normality, linearity, and multicollinearity were tested $(p<0.05)$. Pearson's coefficients were estimated among all variables. The chi-square test was used to determine whether there was evidence to reject $\mathrm{H}_{0}$ (CRUZ, 2013). Next, linear regression analysis was performed using the Stepwise method ( $p \leq 0.15$ ), and the contribution of each variable for the characters was calculated from the partial determination coefficient. For this, the meteorological variables were considered independent input variables, and the morphological characters were considered dependent variables, and all interactions between meteorological variables and morphological characters were tested.

\section{RESULTS AND DISCUSSION}

During sugarcane cultivation in Frederico Westphalen, the average air temperature was $21.2^{\circ} \mathrm{C}$ (range, $0.9^{\circ} \mathrm{C}$ to $34.9^{\circ} \mathrm{C}$; Figure 2), accumulated global solar radiation was $4979 \mathrm{MJ} \mathrm{m}^{-2}$ day $^{-1}$ (Figure 1), accumulated precipitation was $1395 \mathrm{~mm}$, and accumulated water deficit was $20 \mathrm{~mm}$ (Figure 3). In Cruz Alta, the average air temperature was $19.6^{\circ} \mathrm{C}$ (range, $-1.6^{\circ} \mathrm{C}$ to $35.5^{\circ} \mathrm{C}$ ), accumulated global solar radiation was $6097 \mathrm{MJ} \mathrm{m}^{-2} \mathrm{da}^{-1}$, accumulated

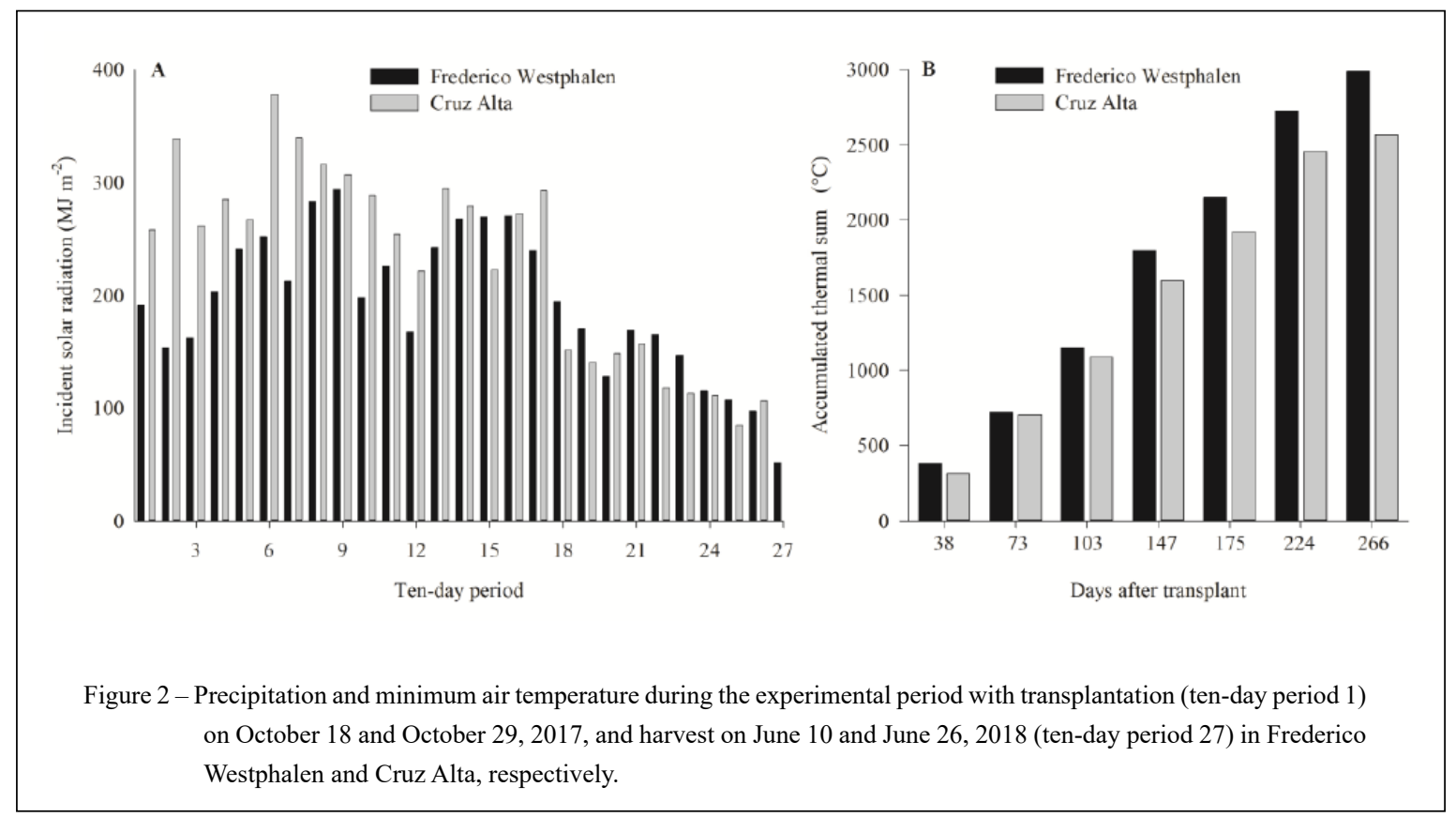

Ciência Rural, v.51, n.10, 2021. 


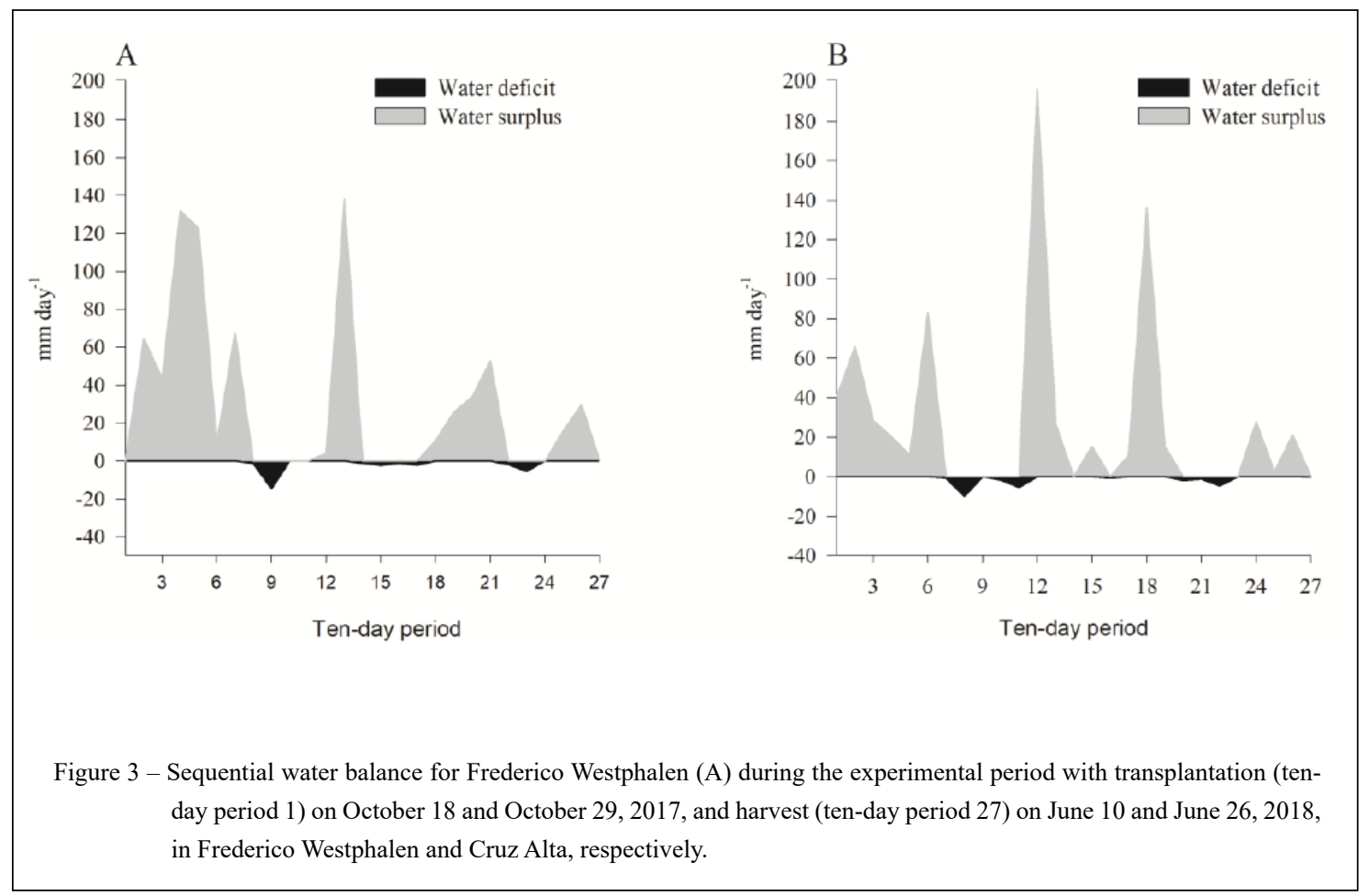

precipitation was $1383 \mathrm{~mm}$, and accumulated water deficit was $23 \mathrm{~mm}$.

Sugarcane cultivation requires average air temperature of above $21^{\circ} \mathrm{C}$ (LOPES \& LIMA, 2015) and adequately distributed accumulated precipitation of $1000 \mathrm{~mm}$ (INMAN-BAMBER $\&$ SMITH, 2005) to promote ideal growth and development. The water deficit observed in both the locations did not coincide with the critical development periods of the crop. Moreover, MAURI et al. (2017) indicated that accumulated water deficit of less than $40 \mathrm{~mm}$ does not negatively impact the growth and development of sugarcane. Thus, water conditions were not limiting factors to the crop.

The multicollinearity test suggested the need to exclude the variables average and maximum air temperature; thermal amplitude; accumulated solar radiation; accumulated precipitation; and minimum, average, and maximum relative humidity from the correlation analysis. Thus, the meteorological variables selected to generate the regression models were minimum air temperature, solar radiation, precipitation, and accumulated thermal sum (degrees-day).

Pearson's correlation analysis showed that the meteorological variable most correlated with the morphological characters responsible for productivity is accumulated thermal sum, with a degree of correlation from regular to very strong (Table 1). Similarly, CAETANO \& CASAROLI (2017) reported a positive correlation between thermal sum and sugarcane productivity. This result can be explained by the fundamental role of thermal sum in the production of photosynthetic units, the production of photoassimilates, and the growth of stem biomass (SINGELS \& BEZUIDENHOUT, 2002), which are determining factors in sugarcane productivity.

Canonical correlation analysis revealed significant effects for the first and second canonical pairs with coefficient $r=0.97$ and 0.74 for Frederico Westphalen and coefficient $r=0.98$ and 0.67 for Cruz Alta, respectively, revealing associations between morphological characters and meteorological variables (Table 2). Thus, any change in any meteorological variable might directly influence some morphological character, and thus affect productivity.

The highest absolute value of group I in the first canonical pair was found for the stem height character, which was positive with a correlation of 0.98 and 0.99 for Frederico Westphalen and Cruz Alta; respectively, being positively associated with the accumulated thermal sum (accumulated degrees-day) and negatively associated with the other variables.

Ciência Rural, v.51, n.10, 2021. 
Table 1 - Pearson's correlation between morphological characters of sugarcane and meteorological variables for Frederico Westphalen and Cruz Alta.

\begin{tabular}{|c|c|c|c|c|c|c|c|}
\hline \multirow[b]{2}{*}{ Variables } & & \multicolumn{3}{|c|}{----------------Frederico Westphalen--------------- } & \multicolumn{3}{|c|}{--------------------------'Cruz Alta---------------------- } \\
\hline & & Correlation & Degree of & Values & Correlation & Degree of & Values \\
\hline \multirow{4}{*}{ SD } & Tmin & 0.133 & Weak & $14.21^{\mathrm{ns}}$ & -0.017 & Weak & $817.19^{\text {ns }}$ \\
\hline & Pre & -0.512 & Regular & $0^{*}$ & -0.053 & Weak & $502.89^{\mathrm{ns}}$ \\
\hline & $\operatorname{Rad}$ & 0.007 & Weak & $896.39^{\mathrm{ns}}$ & -0.565 & Regular & $0^{*}$ \\
\hline & ATS & 0.817 & Strong & $0^{*}$ & 0.758 & Strong & $0^{*}$ \\
\hline \multirow{4}{*}{ SH } & Tmin & -0.141 & Weak & $9.49^{\text {ns }}$ & -0.288 & Weak & $0.22^{*}$ \\
\hline & Pre & -0.407 & Regular & $0^{*}$ & -0.007 & Weak & $922.57^{\mathrm{ns}}$ \\
\hline & $\operatorname{Rad}$ & -0.206 & Weak & $0.21^{*}$ & -0.769 & Strong & $0^{*}$ \\
\hline & ATS & 0.969 & Very strong & $0^{*}$ & 0.972 & Very strong & $0^{*}$ \\
\hline \multirow{4}{*}{ NSM } & Tmin & 0.486 & Regular & $0^{*}$ & -0.365 & Regular & $0^{*}$ \\
\hline & Pre & -0.585 & Regular & $0^{*}$ & -0.140 & Weak & $66.4^{\mathrm{ns}}$ \\
\hline & $\mathrm{Rad}$ & 0.200 & Weak & $0.32^{*}$ & -0.321 & Regular & $0.04^{*}$ \\
\hline & ATS & 0.383 & Regular & $0^{*}$ & 0.532 & Regular & $0^{*}$ \\
\hline
\end{tabular}

${ }^{*}$ significant at 5\% probability; ${ }^{\text {ns }}$ not significant; $\mathrm{SD}=$ stem diameter; $\mathrm{SH}=$ stem height; NSM $=$ number of stems per meter; Rad $=$ solar radiation; Tmin = minimum temperature; Pre = precipitation; ATS = accumulated thermal sum.

In the second canonical pair, at both locations, the highest absolute value for group I was observed for the number of stems per meter (NSM) character, with a correlation of 0.77 and 0.81 for Frederico Westphalen and Cruz Alta, respectively. NSM was positively associated with minimum temperature and negatively associated with pluviometric precipitation. Thus, increases in the minimum air temperature might imply higher emission of tillers, which, in turn, directly affects crop productivity (ESPÓSITO et al., 2012; FABRIS et al., 2013). Similar results were obtained by ARAÚJO et al. (2017) for sugarcane cultivation in southern Brazil.

In the Stepwise method, the first variable to be included was accumulated thermal sum (ATS), which most contributed to the models. Conversely, solar radiation was the variable with the lowest participation in the models, indicating a secondary effect of this variable on the productivity of sugarcane in Rio Grande do Sul. CARON et al. (2018) evaluated the productivity of sugarcane in agroforestry systems and reported productivity above 60 tons of stalks per hectare, which is compatible with the average for southern Brazil (CONAB, 2018) when cultivated under a reduction of $20 \%$ in the incidence of solar radiation. Therefore, these results corroborated those observed in this study, which showed that solar radiation was not the main determinant of sugarcane productivity.

The equations generated by Stepwise regression indicated the need to include more than one meteorological variable in the models (Table 3), corroborating the results obtained by SCHWERZ (2017) for cultivating sugarcane in an agroforestry system. Thus, the productivity of sugarcane can be assumed to be not affected by an isolated meteorological variable, but by a combination of variables. Moreover, KUMAR et al. (2016) showed that the combined use of meteorological variables and yield components allowed an adequate estimation of sugarcane productivity.

In the Stepwise method, the yield component that obtained the highest determination coefficient was plant height, with values of 0.95 and 0.96 for Frederico Westphalen and Cruz Alta, 
Table 2 - Canonical loads for the characters that determine the production of tons of stalks per hectare at the two sites Frederico Westphalen and Cruz Alta. The experiment at Frederico Westphalen was conducted under two densities and that at Cruz Alta under a single planting density.

\begin{tabular}{|c|c|c|c|c|c|c|c|}
\hline \multirow{3}{*}{ Variables } & \multicolumn{3}{|c|}{ Frederico Westphalen } & & \multicolumn{3}{|c|}{ Cruz Alta } \\
\hline & \multicolumn{4}{|c|}{--------------------------Group I------------------------- } & \multicolumn{3}{|c|}{-------------------------'Group I------------------------- } \\
\hline & $1^{0 *}$ & $2^{\mathrm{o} *}$ & $3^{\circ}$ & & $1^{0 *}$ & $2^{o *}$ & $3^{\circ}$ \\
\hline SD & 0.88491 & 0.23333 & 0.40309 & SD & 0.88491 & 0.23333 & 0.40309 \\
\hline $\mathrm{SH}$ & 0.98507 & -0.1695 & 0.03016 & $\mathrm{SH}$ & 0.98507 & -0.1695 & 0.03016 \\
\hline \multirow[t]{2}{*}{ NSM } & 0.49106 & 0.77325 & -0.4012 & NSM & 0.49106 & 0.77325 & -0.4012 \\
\hline & \multicolumn{4}{|c|}{--------------------------Group II------------------------- } & \multicolumn{3}{|c|}{--------------------------'Group II-------------------------. } \\
\hline Tmin & -0.0313 & 0.88018 & 0.08638 & Tmin & -0.0313 & 0.88018 & 0.08638 \\
\hline Pre & -0.4975 & -0.5686 & 0.23232 & Pre & -0.4975 & -0.5686 & 0.23232 \\
\hline $\operatorname{Rad}$ & -0.1463 & 0.53774 & 0.50427 & $\operatorname{Rad}$ & -0.1463 & 0.53774 & 0.50427 \\
\hline ATS & 0.98287 & -0.1657 & -0.0769 & ATS & 0.98287 & -0.1657 & -0.0769 \\
\hline $\mathrm{r}$ & 0.97 & 0.74 & 0.19 & $\mathrm{r}$ & 0.97 & 0.74 & 0.19 \\
\hline GL & 12 & 6 & 2 & GL & 12 & 6 & 2 \\
\hline
\end{tabular}

*Significant canonical pair by the $5 \%$ chi-square test; $\mathrm{SD}=$ stem diameter; $\mathrm{SH}=$ stem height; NSM = number of stems per meter; Tmin $=$ minimum temperature; Pre = precipitation; $\operatorname{Rad}=$ solar radiation; $\mathrm{ATS}=$ accumulated thermal sum.

respectively. Moreover, ATS was the variable with the greatest contribution to the models at both the locations. KUMAR et al. (2016) revealed greater contribution of precipitation to the models, but in southeastern Brazil. These differences in results are attributed to the climatic differences between the regions, with the southeast region having lower precipitation and higher temperatures compared to the south region (ALVARES et al., 2013), indicating that the most important element limiting the cultivation of sugarcane in this case is precipitation.

Pearson's correlation, canonical correlation, and Stepwise regression analyses indicated that the most important meteorological variable for the growth and development of sugarcane in the central and northwest regions of the state of Rio Grande do Sul is air temperature, i.e., the ATS. This result differs from those of most studies reported in the literature, in which the main variable that determines the growth and development of sugarcane is precipitation (DIAS et al., 1999; DARLI et al., 2008; LI \& YANG, 2014; KUMAR et al., 2016; ANDRADE JUNIOR et al., 2017). However, in the studied regions, the annual precipitation ranges from $1990 \mathrm{~mm}$ to 2500 $\mathrm{mm}$, which is 500 to $1000 \mathrm{~mm}$ higher than that in the regions where sugarcane is traditionally grown (ALVARES et al., 2013). This volume, associated with the uniform distribution of precipitation (isoigro regime, i.e., normal rainfall values are well distributed throughout the year) in the southern region, does not affect sugarcane growth.

Thus, sugarcane breeding programs in southern Brazil must prioritize the development of genotypes with greater tolerance to low temperatures and less thermal demand, to boost the sugar-energy industry and contribute to the development of the industry in this region. This would decrease the energy dependence of the region and thus contribute to the research carried out in the improvement program of the Federal University of Santa Maria, which focuses on developing cultivars with lower thermal requirements for growth (KNAPP et al., 2019).

\section{CONCLUSION}

The regression models revealed the importance of temperature for the growth and development of sugarcane. The outcomes of the models suggested that the growth of sugarcane responds positively to the thermal sum and is less influenced by solar radiation and precipitation in the studied locations.

The results showed that the sugarcane crop can be explored in the studied locations, and sugarcane breeding programs in southern Brazil 
Table 3 - Regression models for the morphological characters stem diameter (SH). stem height (SH). and number of stems per linear meters of furrow (NSM), which are responsible for sugarcane productivity in Frederico Westphalen and Cruz Alta.

\begin{tabular}{|c|c|c|c|}
\hline Place & Regression equation & $\mathrm{R}^{2}$ & Contribution \\
\hline \multirow{10}{*}{ Frederico W. } & \multirow{3}{*}{$\begin{aligned} \mathrm{SD}=0.959 & +0.041(\mathrm{Tmin})-0.001(\text { Pre }) \\
& +0.001(\mathrm{ATS})\end{aligned}$} & \multirow{3}{*}{0.76} & $\mathrm{ATS}=66.8 \%$ \\
\hline & & & $\operatorname{Tmin}=8.9 \%$ \\
\hline & & & Pre $=0.9 \%$ \\
\hline & \multirow{4}{*}{$\begin{array}{c}\mathrm{SH}=-105.956-4.585(\mathrm{Tmin})-0.127(\text { Pre }) \\
+0.212(\mathrm{Rad})+0.149(\mathrm{ATS})\end{array}$} & \multirow{4}{*}{0.95} & $\mathrm{ATS}=93.9 \%$ \\
\hline & & & $\operatorname{Rad}=0.5 \%$ \\
\hline & & & $\operatorname{Tmin}=0.1 \%$ \\
\hline & & & Pre $=0.2 \%$ \\
\hline & \multirow{3}{*}{$\begin{aligned} \mathrm{NSM}=8.53 & +0.711(\mathrm{Tmin})-0.002(\text { Pre }) \\
& +0.002(\text { ATS })\end{aligned}$} & \multirow{3}{*}{0.57} & Pre $=34.3 \%$ \\
\hline & & & $\operatorname{Tmin}=15.0 \%$ \\
\hline & & & $\mathrm{ATS}=7.8 \%$ \\
\hline \multirow{7}{*}{ Cruz Alta } & \multirow{2}{*}{$\mathrm{SD}=0.406+0.0007(\mathrm{Rad})+0.0008(\mathrm{ATS})$} & \multirow{2}{*}{0.59} & $\mathrm{ATS}=57.5 \%$ \\
\hline & & & $\operatorname{Rad}=2.1 \%$ \\
\hline & \multirow{3}{*}{$\begin{aligned} \mathrm{SH}=-168.864 & -2.412(\mathrm{Tmin})+0.141(\mathrm{Rad}) \\
& +0.195(\mathrm{ATS})\end{aligned}$} & \multirow{3}{*}{0.96} & $\mathrm{ATS}=94.5 \%$ \\
\hline & & & $\operatorname{Rad}=1.0 \%$ \\
\hline & & & $\operatorname{Tmin}=0.4 \%$ \\
\hline & \multirow{2}{*}{$\mathrm{NSM}=0.021+0.69(\mathrm{Tmin})+0.005(\mathrm{ATS})$} & \multirow{2}{*}{0.58} & $\mathrm{ATS}=28.3 \%$ \\
\hline & & & $\operatorname{Tmin}=29.3 \%$ \\
\hline
\end{tabular}

ATS $=$ accumulated thermal sum; $\operatorname{Rad}=$ solar radiation; Tmin $=$ minimum temperature; Pre $=$ precipitation

should prioritize research on tolerance to abiotic stress, especially minimum temperature, thereby decreasing the thermal constant of the crop to complete the cycle and increase productivity.

\section{ACKNOWLEDGMENT}

The research was financed in part by the Coordenação de Aperfeiçoamento de Pessoal de Nível Superior (CAPES), Brasil - Finance code 001.

\section{AUTHORS' CONTRIBUTION}

All authors contributed equally to the design and drafting of the manuscript. All authors critically reviewed the manuscript and approved the final version.

\section{DECLARTION OF CONFLICT OF INTERESTS}

The authors declare no conflict of interest. The founding sponsors had no role in the design of the study; in the collection, analyses, or interpretation of data; in the writing of the manuscript, and in the decision to publish the results

\section{REFERENCES}

ALVARES, C.A., et al. Köppen's climate classification map for Brazil. Meteorologische Zeitschrift, v.22, n.6, p.711-728. 2013. Disponível em: <https://www.schweizerbart.de/papers/metz/detail/22/82078/ Koppen_s_climate_classification_map_for_Brazil $>$. Acesso em: 20 nov. 2018. doi: 10.1127/0941-2948/2013/0507.

ANDRADE JUNIOR, S. D. A., et al. Water demand of sugarcane, through the energy balance method, at Teresina region, Piauí State, Brazil. agrometeoros, v.25, n.1, p.217-226. 2017. Disponível em: <https://seer.sct.embrapa.br/index.php/agrometeoros/article/ view/26282>. Acesso em: 08 out. 2018. doi: 10.31062/agrom. v25i1.26282.

ARAÚJO, R. M. et al. Agrometeorological conditions from maximum perfilmation of sugarcane culture in two differents environments of production. Agrometeoros, v. 25, p. 257-264, 2017. Disponível em: https://seer.sct.embrapa.br/index.php/agrometeoros/article/view/26287. Acesso em: 08 out. 2020. doi: 10.31062/agrom.v25i1.26275. 
BOCCA, F. F.; L. H. A. RODRIGUES. The effect of tuning, feature engineering, and feature selection in data mining applied to rainfed sugarcane yield modelling. Computers and Electronics in Agriculture, v.128, p.67-76. 2016. Disponível em: <https:// www.sciencedirect.com/science/article/pii/S0168169916306391>. Acesso em: 10 nov. 2018. doi: 10.1016/j.compag.2016.08.015.

CAETANO, M. J.; CASAROLI, D. Sugarcane yield estimation for climatic conditions in the center of state of Goiás. Revista Ceres, v. 64, p. 298-306, 2017. Disponível em: <https://www.scielo.br/pdf/ rceres/v64n3/2177-3491-rceres-64-03-00298.pdf >. Acesso em: 08 out. 2020. doi: 10.1590/0034-737X201764030011.

CAPUTO, M. M., et al. Response of sugarcane genotypes to the application of ripeners. Bragantia, v.67, n.1, p.15-23. 2008 Disponível em: $\quad<$ http://www.scielo.br/scielo.php?script $=$ sci arttext\&pid $=$ S0006-87052008000100002\&lng $=$ pt\&tlng $=$ pt $>$. Acesso em: 11 nov. 2018. doi: 10.1590/S0006-87052008000100002.

CARON, B. O., et al. Growth of tree species and sugarcane production in agroforestry systems. An Acad Bras Cienc, v.90, n.2 suppl 1, p.2425-2436. 2018. Disponível em: <http://www.ncbi. nlm.nih.gov/pubmed/30066745>. Acesso em: 02/11/2018. doi: 10.1590/0001-3765201820170313.

CARVALHO, I. R., et al. Canonical correlations between morphological traits and yield components in dual-purpose wheat. Pesquisa Agropecuária Brasileira, v.50, n.8, p.690-697. 2015. Disponível em: http://www.scielo.br/pdf/pab/v50n8/1678-3921-pab-50-08-00690.pdf . Acesso em: 01/11/2018. doi: 10.1590/S0100-204X2015000800007.

CASTRO-NAVA, S., et al. Leaf growth and canopy development of three sugarcane genotypes under high temperature rainfed conditions in northeastern Mexico. International Journal of Agronomy, v. 2016, p.1-7. 2016. Disponível em: <https://www.hindawi.com/journals/ ija/2016/2561026/>. Acesso em: 28 set. 2018. doi: 10.1155/2016/2561026.

CONAB - Companhia Nacional de Abastecimento. Acompanhamento da safra brasileira de cana-de-açúcar, segundo levantamento - safra 2020-2021. 2020. Disponível em: <https:// www.conab.gov.br/info-agro/safras/cana>. Acesso em: 09 out, 2020.

CONAB. Acompanhamento da safra brasileira de cana-de-açúcar. Companhia nacional de abastecimento. Brasilia: Conab. 52018.

CRUZ, C. D. GENES - a software package for analysis in experimental statistics and quantitative genetics. Acta Scientiarum, v.35, n.3, p.271-276. 2013. Disponível em: https://www.scielo.br/ scielo.php?script $=$ sci_arttext\&pid=S1807-86212013000300001. Acesso em: 01 nov. 2018. Doi: 10.4025/actasciagron.v35i3.21251.

DARLI, A. B., et al. Irrigação por gotejamento subsuperficial na produção e qualidade de cana-de-açúcar. Irriga, v.13, n.1, p.111. 2008. Disponível em: <http://revistas.fca.unesp.br/index.php/ irriga/article/view/3340/2101>. Acesso em: 03 nov. 2018. doi: 10.15809/irriga.2008v013n1p1-11.

DIAS, F. L. F., et al. Productivity of sugarcane in relation to climate and soils of the northwestern São Paulo state. Revista Brasileira de Ciência do Solo, v.23, n.3, p.627-634. 1999. Disponível em: $<$ http://www.scielo.br/scielo.php?script=sci_arttext\&pid=S0100$06831999000300016 \& \operatorname{lng}=\mathrm{en} \& \mathrm{nrm}=\mathrm{iso} \& \operatorname{tlng}=\mathrm{pt}>$. Acesso em: 01 nov. 2018. doi: 10.1590/S0100-06831999000300016.

ESPÓSITO, D. P. et al. Path analysis using phenotypic and genotypic values for yield components in the selection of sugarcane families. Ciência Rural, v. 42, p. 38-44, 2012. Disponível em: $<$ https://www.scielo.br/pdf/cr/v42n1/a1312cr5534.pdf $>$. Acesso em: 08 out. 2020. doi: 10.1590/S0103-84782011005000152.

EVERINGHAM, Y., et al. Accurate prediction of sugarcane yield using a random forest algorithm. Agronomy for Sustainable Development, v.36, n.2, p.27. 2016. Disponível em: $<$ https://doi. org/10.1007/s13593-016-0364-z>. Acesso em: 31 set. 2018. doi: 10.1007/s13593-016-0364-z.

FABRIS, L. B., et al. Productivity and performance of the sugarcane grown at different spacings and rates of nitrogen sidedressing. Revista Agrarian, v.6, n.21, p.252-258. 2013. Disponível em: $<$ http://ojs.ufgd.edu.br/index.php/agrarian/article/view/2019>. Acesso em: 29 set. 2018.

FIORENTIN, L. D., et al. Quantificação e modelagem de biomassa e carbono da regeneração natural em área de floresta ombrófila mista. Revista Brasileira de Biometria, v.33, p.261-267. 2015. Disponível em: <http://jaguar.fcav.unesp.br/RME/fasciculos/v33/ v33_n2/A9_Luan_AnaPaula.pdf $>$. Acesso em: 30 nov. 2018

INMAN-BAMBER, N. G.; SMITH, D. M. Water relations in sugarcane and response to water deficits. Field Crops Research, v. 92, p. 185-202, 2005. Disponível em: <https://www.sciencedirect. com/science/article/abs/pii/S0378429005000249>. Acesso em: 07 out. 2020. doi: 10.1016/j.fcr.2005.01.011.

KNAPP, F. M., et al. Thermal sum for the establishment of new sugarcane cultivars. Agrometeoros, PassoFundo, v.27, n.2, p.409415, dez 2019. Disponivel em: https://seer.sct.embrapa.br/index. php/agrometeoros/article/view/26457 Acesso em 09 out 2019. doi: 10.31062/agrom.v27i2.26457.

KUMAR, N., et al. Crop yield forecasting of paddy and sugarcane through modified Hendrick and Scholl technique for South Gujarat, v.67. 2016. 405-410 p.

LI, Y.-R.; L.-T. YANG. Sugarcane Agriculture and Sugar Industry in China. Sugar Tech, v.17, n.1, p.1-8. 2014. Disponível em: $<$ https://link.springer.com/article/10.1007/s12355-014-0342-1>. Acesso em: 10 dez. 2018. doi: 10.1007/s12355-014-0342-1.

LOPES, N. F.; LIMA, M. G. S. Fisiologia da Produção. Viçosa, MG: Editora UFV. 2015. 492 p.

MARTINS, A. L. M.; M. G. A. LANDELL. Conceitos e critérios para avaliação experimental em cana-de-açúcar utilizados no Programa Cana IAC. Pindorama: Instituto Agronômico: 45 p. 1995.

MAURI, R., et al. Water Relations at the Initial Sugarcane Growth Phase under Variable Water Deficit. Engenharia Agrícola, v.37, n.2, p.268-276. 2017. Disponivel em <https:// www.scielo.br/scielo.php? script $=$ sci arttext\&pid $=$ S0100$69162017000200268 \& \operatorname{lng}=$ en $\& n r m=i s o>$ Acesso em 05 out 2020. doi: 10.1590/1809-4430-eng.agric.v37n2p268-276/2017.

MORAIS, K. P., et al. Dinâmica da parte aérea em cana-de-açúcar. Stab, v.36, n.3, p.35-37. 2018. Disponível em: <http://www. stab.org.br/Artigos $\% 20 \mathrm{de} \% 20 \mathrm{Capa} /$ revista janfev2018 web. pdf?fbclid=IwAR1Gn1fb_4b8VOPE4kgdFAaMX3M4h0UT7TUP3mDkF9ddD-qyyPCFC $\bar{C} 0 \mathrm{BgY}>$. Acesso em: 20 nov. 2018.

NOVA, N. A. V., et al. Estimativa de graus-dia acumulados acima de qualquer temperatura base, em função das 
temperaturas máxima e mínima: Universidade de São Paulo, Instituto de Geografia. 1972.

OLIVEIRA, R. A. D., et al. Leaf area in three sugar-cane cultivars and its relationship with biomass production. Pesquisa Agropecuária Tropical, v.37, n.2, p.71-76. 2007. Disponível em: $<\mathrm{http}$ ://www.redalyc.org/articulo.oa? $\mathrm{id}=253020281002>$. Acesso em: 21 ago. 2018

PAGANI, V., et al. Forecasting sugarcane yields using agroclimatic indicators and Canegro model: A case study in the main production region in Brazil. Agricultural Systems, v.154, p.4552. 2017. Disponível em: <https:/www.sciencedirect.com/science/ article/pii/S0308521X16308095?via\%3Dihub>. Acesso em: 10 nov. 2018. doi: 10.1016/j.agsy.2017.03.002.

PEREIRA, A. R., et al., Agrometeorologia: Fundamentos e aplicação pratica. Guaiba: Livraria e Editora agropecuaria Ltda., 2002. 478 p.

SCHWERZ, F., et al., Assessing Yield, Growth and Climate Traits in Agroforestry Systems in Southern Brazil. Journal of Sustainable Forestry, v. 39, p. 1-20, 2020. Disponível em: https:/www.tandfonline.com/doi/abs/10.1080/10549811.2020 .1746913 ? journalCode=wjsf20. Acesso em: 15 set. 2020 . doi: 10.1080/10549811.2020.1746913.

SILVA, M. A., et al. Yield potential of sugarcane under drip irrigation in function of varieties and crop cycles. Revista Brasileira de Engenharia Agrícola e Ambiental, v.18, n.3, p.241-249. 2014. Disponível em: <http://www.scielo.br/scielo.php?script=sci artte
xt\&pid=S1415-43662014000300001>. Acesso em: 12 nov. 2018. doi: $10.1590 /$ S1415-43662014000300001.

SINGELS, A.; BEZUIDENHOUT, C. N. A new method of simulating dry matter partitioning in the Canegro sugarcane model. Field Crops Research, v. 78, p. 151-164, 2002. Disponível em: <https://www. sciencedirect.com/science/article/abs/pii/S0378429002001181>. Acesso em: 08 out. 2020. doi: 10.1016/S0378-4290(02)00118-1.

SOCIEDADE BRASILEIRA DE CIÊNCIA DO SOLO. Manual de calagem e adubação para o estado do Rio Grande do Sul e de Santa Catarina: Sociedade Brasileira de Ciência do Solo Núcleo Regional Sul. - [s. 1.] : Comisão de Química e Fertilidade do Solo - RS/SC. 2016.

STRECK, N. A., et al. Leaf development and growth of selected sugarcane clones in a subtropical environment. Pesquisa Agropecuária Brasileira, v.45, n.10, p.1049-1057. 2010. Disponível em: $<$ http://www.scielo.br/scielo.php?script=sci arttext\&pid=S0100-204X2010001000001 $>$. Acesso em: 13 nov. 2018. doi: 10.1590/S0100-204X2010001000001.

SUGUITANI, C. Entendendo o crescimento e produção da cana-deaçúcar: avaliação do modelo Mosicas. Universidade de São Paulo. Escola Superior de Agricultura “Luiz de Queiroz", Piracicaba, 2006. 60 p.

WALTER, A., et al. Brazilian sugarcane ethanol: developments so far and challenges for the future. Wires: Energy Environment, v.3, n.1, p. 70-92, Jan/Feb 2014. Disponível em: https://onlinelibrary.wiley.com/ doi/abs/10.1002/wene.87 Acesso em 21 set 2020. doi: 10.1002/wene.87. 